\title{
The pedagogical role of multicultural leadership in post- apartheid South Africa
}

\begin{tabular}{|c|c|}
\hline \multicolumn{2}{|c|}{$\begin{array}{l}\text { Authors: } \\
\text { Gordon E. Dames } \\
\text { Glenda A. Dames }^{1}\end{array}$} \\
\hline \multicolumn{2}{|c|}{$\begin{array}{l}\text { Affiliations: } \\
{ }^{1} \text { Department of Philosophy, } \\
\text { Practical and Systematic } \\
\text { Theology, University of South } \\
\text { Africa, South Africa }\end{array}$} \\
\hline \multicolumn{2}{|c|}{$\begin{array}{l}\text { Note: } \\
\text { This article was initially a } \\
\text { paper titled 'Spirituality, } \\
\text { leadership and social } \\
\text { transformation: The } \\
\text { pedagogical role of } \\
\text { multicultural leadership } \\
\text { in a post-apartheid South } \\
\text { Africa', presented at the } \\
\text { International Association } \\
\text { of Practical Theology's } \\
\text { Conference, 'Complex } \\
\text { identities in a shifting world: } \\
\text { One God many stories', } \\
\text { Emmanuel College of Victoria } \\
\text { University in the University } \\
\text { of Toronto, Toronto, Canada, } \\
\text { April 11-15, 2013. }\end{array}$} \\
\hline \multicolumn{2}{|c|}{$\begin{array}{l}\text { Correspondence to: } \\
\text { Gordon Dames }\end{array}$} \\
\hline \multicolumn{2}{|c|}{$\begin{array}{l}\text { Email: } \\
\text { damesge@unisa.ac.za }\end{array}$} \\
\hline \multicolumn{2}{|c|}{$\begin{array}{l}\text { Postal address: } \\
\text { PO Box 392, University of } \\
\text { South Africa 0003, South } \\
\text { Africa }\end{array}$} \\
\hline \multicolumn{2}{|c|}{$\begin{array}{l}\text { Dates: } \\
\text { Received: } 03 \text { Dec. } 2013 \\
\text { Accepted: } 13 \text { Mar. } 2013 \\
\text { Published: } 09 \text { July } 2014\end{array}$} \\
\hline \multicolumn{2}{|c|}{$\begin{array}{l}\text { How to cite this article: } \\
\text { Dames, G.E. \& Dames, G.A., } \\
\text { 2014, 'The pedagogical role } \\
\text { of multicultural leadership in } \\
\text { post-apartheid South Africa', } \\
\text { HTS Teologiese Studies/ } \\
\text { Theological Studies 70(1), } \\
\text { Art. \#2106, } 9 \text { pages. http:// } \\
\text { dx.doi.org/10.4102/hts. } \\
\text { v70i1.2106 }\end{array}$} \\
\hline \multicolumn{2}{|c|}{$\begin{array}{l}\text { Copyright: } \\
\text { (C) 2014. The Authors. } \\
\text { Licensee: AOSIS } \\
\text { OpenJournals. This work } \\
\text { is licensed under the } \\
\text { Creative Commons } \\
\text { Attribution License. }\end{array}$} \\
\hline \multicolumn{2}{|l|}{ Read online: } \\
\hline arifta & $\begin{array}{l}\text { Scan this QR } \\
\text { code with your } \\
\text { smart phone or } \\
\text { mobile device } \\
\text { to read online. }\end{array}$ \\
\hline
\end{tabular}

Practical theology in the 21st century is faced with increasing diversity that requires a new pedagogy to address multicultural challenges. Multiculturalism serves as a subversive agency for monocultural and 'silent minority' landscapes. It might also contribute to the development of an identity pedagogue for the three public spaces of theology, specifically in South Africa, where this new democracy seeks a new culture of humanity and has to deal with the dichotomy of a multicultural society and a resistant monocultural 'laager' mentality of minority races. Despite the promising start to its democracy, South Africa has many social challenges and practical theology has a role to play by reflecting on how we understand and embody the relationship between faith, culture and public life. To this end, this article seeks to reflect critically on spirituality, leadership and social transformation praxis in search of meaning-forming multicultural praxes.

\section{Introduction}

The postcolonial era offers unique opportunities for Christianity to interact with diverse cultures in the world, not as a missionizing force or a conquering ideology. With the shift of demographics of Christians ... Christianity is on the threshold of becoming more multicultural than before, and must open itself to learn from other traditions. (Pui-lan 2005:69-70)

As part of sub-Saharan Africa, South Africa has many complex social and multicultural ${ }^{1}$ challenges $^{2}$ which relate to colonisation, class, race and socio-economic issues.

Practical theology, however, lacks a reflective praxis to address multicultural issues (Andrews 2002:29). Racial integration and communal faith praxes are critical (Schoeman et al. 2012:136). The three publics of theology (cf. Tracy 1981:14ff. below) are failing to address racism and new forms of discrimination (Batts 1989:18-29). South Africans are in dire need of interrelationships across colour- and cultural boundaries to foster human dignity. We are now living on the fault lines of widespread cultural change (Van Rooi 2010:171). A shift from the centre to the edges of contemporary culture is characteristic of global changes (Taylor 2005:9):

[Pedagogical] transformation is not only about changing systems and structures, but that on a deeper level it is about the transformation of relationships and attitudes between the different cultural groups in South Africa. ... It is a simple human principle that it is often experienced only through exposure to one another, through 'inter-action', through seeing and experiencing face to face, that the opinions and approaches of people change over time. ... it is in exactly the failure to face the other, rather opting for the safety of the enclave, that a major stumbling block for transformation in South Africa can be found. (Cilliers \& Nell 2011:1).

This article seeks to highlight some of these challenges as it relates to sacred and secular leadership (on all levels of society) from a practical theological perspective, taking into account the role of spirituality and multicultural leadership. A pedagogy of leadership as an agogical (transformational) process that entails critical functioning in search of appropriate theory development in service of the totality of our praxes, is required (Firet 1968:223). The pedagogical framework of this article consists of the work of Firet (1968), Freire (1972) and Ploeger (1995). The applied practical theological pedagogical ${ }^{2}$ methodology consists of a descriptive-empirical perspective (Heitink 1993:17). Retrospective participation in and observations about the cultural dynamics in diverse church, societal and institutional contexts are based on our collective experiences in church ministry, the academia and community service in different

1.It refers to anti-racist and diverse cultural realities and a new postcolonial appreciation for the "other' (Venter 2008:543) or the "legacy of other cultures' (De Gruchy 2000:46). The concept 'culture' is about everything that constitutes human perceptions, thinking and living, for instance, our beliefs, values codes of conduct, world view, rituals, ubuntu spirit, language, food, clothing and music (Bevans \& Schroeder 2004:47)

2.Paulo Freire's pedagogy of oppression and freedom provides us with essential principles for this study (Clarke 1998:x). Competency of critical consciousness is sought in whether and how leaders contextualise themselves in their own historicity, for instance, to understand the colonial, class, race and socio-political conditions and formations that shape their respective contexts (Aronowitz 1998:14). 
non-governmental organisations between 1985 and 2014 summarised as a 'general process of spiritual development of humanity as a whole' (Degenaar 2000:155).

It is for this reason that we draw on Loder's (as analysed by Kovacs 2011:167-175) insights to introduce the aspect of spirituality into a pedagogy of spiritual, multicultural leadership. According to Loder (cited in Kovacs 2011:170), the primary role of the church is 'to nurture the human spirit, by helping the self to come to a true identity.' The controversial argument by DeYoung et al. (2003:2) that the 'twenty-first century must be the century of multiracial congregations' is in essence a question about the transformation of human identity. Loder urges the Christian church to reaffirm that it is essentially about cultural transformation (Kovacs 2011:167). ${ }^{3}$ A pedagogy of transformation seeks to transform colonised and racialised relationships and attitudes between different cultural groups (Tracy 1981:14). We should be mindful that the colonisation process is 'both social and political as well as cultural and discursive' (Pui-lan 2005:2). It is essential for dialogue between the three publics, namely the church, society and academia in theology (Tracy 1981:14ff.). The transversality between the latter and Douglas's (2007:1-14) theory of the three social contexts, namely, the market, the hierarchy, and the enclave is crucial - as it relates to human or leadership behaviour, tendencies and values. The market refers to an individualistic commercial culture as opposed to collective, group cultures. The hierarchy refers to wealth and power which dominate egalitarian values. The enclave is a small group that has withdrawn from their social environment. The aim is to illuminate how the three publics and these three social contexts interrelate. Tracy (1981:5) contends that theology is essentially public theology that addresses three related social realities, namely: the wider society, the academy and the church. Society refers to politics, socio-economics and culture as it relates to socio-economic and political justice. The academy deals with intellectual and empirical interdisciplinary interaction with the social, human and natural sciences. The church sees to the responsibility and accountability of theologians regarding the lived reality and tradition of Christian faith communities (Tracy 1981:14-24). We seek to address the transversality between these different, but related social realities and, in particular, how they relate or are influenced by the dynamics of the three social contexts (Douglas 2007:1-14; Osmer 2005:312313). ${ }^{4}$ We oppose any tendency of hierarchy, market, individualistic and/or privatisation of theology and prefer contextual public theology (Tracy 1981:30-31). We contend that practical theology fails as a result of the influence of the

3.We need to dismantle the edifice and recurring implications of apartheid in South Africa, and seek the reconstruction of an anti-racist and multicultural society, free of divisions and ethnic domination (Cochrane, De Gruchy \& Petersen 1991:2, 6). The three publics in South Africa are legally obligated to reconstruct discrimination practices in institutions, systems and society (Kuperus 2011:278-306). The rebuilding of an African spirituality of cooperation is required to promote a rebuilding of an African spirituality of cooperation is required to promote a
transverse spirituality for different theologies in the three publics to address the transverse spirituality for different theologies in the three publics to address
relationship between culture and practical theology (Mwambazambi 2011:8).

4.The complexity of multiculturality requires a transversal process of reflexive discernment grounded in the local contexts and experiences of the three publics (Branson \& Martínez 2011:385-390; Osmer 2008:172). three social contexts to address the divide between public and sacred realities of multiculturality (Andrews 2002:29; Venter 2008:542). 'The process of inclusivity in secular and religious institutions will never be complete until the population of the secular society is reflected in the students, faculty, church and society' (Jafta 2000:181-182).

We are in need of spiritual and multicultural transversality praxes.

The role of culture and spirituality in the formation of identity form the basis of the proposed pedagogy to integrate leadership, spirituality and multiculturality (Degenaar 2000:155; Loder in Kovacs 2011:167). We seek to underscore the principles of subverting negative forces (such as 'white flight', 'laager mentality' and 'enclavement') and cultural transformation. Cultural transformation can contribute to foster a new kind of multicultural society ${ }^{5}$ to counter dysfunctional systems and leadership praxes which engender the above-mentioned negative cultural forces. The ethnic composition of the so-called English-speaking (Protestant and Roman Catholic) churches, to a lesser degree, and the mostly Afrikaans-speaking - Dutch Reformed Church (DRC) serve as an example. They have not changed dramatically since the 20th century (De Gruchy 2000:38). ${ }^{6}$ For this reason, an authentic multicultural society developed by secular and sacred leaders in the three publics, are sought.

We recognise that multiculturality is a complex issue and should not be viewed merely as another postmodern concept that denies underlying issues of race and racism (Durrheim, Mtose \& Brown 2011:27; Esterline \& Kalu 2006:7). Rather, this article is of an explorative nature, seeking to view some of the challenges that the church is faced with and reflect on the role spirituality and leadership - that is sensitive to multiculturality - can play in a post-apartheid South Africa (Batts 1989) and elsewhere (Esterline \& Kalu 2006). Postapartheid South Africa refers to the period of transformation in our country; from the oppressive rule of apartheid, to a new democratic society characterised by equality, freedom and justice. In the following section, some of these challenges will be highlighted.

\section{Background and context}

Modern racism, neo-colonialism, internal dominance and oppression, for example, are new forms of resistance in a predominantly multicultural South African context (Batts 1989:18, 22). Accordingly, South Africans continue to experience problems with identity, which is an inherent

5. Refers to a society that '... move $[s]$ beyond multiracialism through nonracialism to multiculturalism that is truly African, yet open to the legacy of other cultures' (De Gruchy 2000:46).

6.The identity of reformed churches is scarred along racial divides: 'The brokenness still plagues these churches until this very day as is visible in the ecclesial story of ... congregation $[s]$... It directly impacts on the reality facing the South African context and it affects the emotional poverty and the dire lack of human dignity that plagues our nation' (Van Rooi 2010:177). The Christian church should attend that plagues our nation' (Van Rooi 2010:177). The Christian church should attend
to the complex dynamics between church, theology and cultural issues (Branson \& Martínez 2011:367) 
struggle of the socialisation of what Andrews (2002:724) calls 'black humanity' (Mwambazambi 2011:5 of 8). Pervasive practices of racism and classism ${ }^{7}$ even amongst black people inhibit the socialisation and re-socialisation of black humanity (Andrews 2002:609, 718). Our inability to bridge monocultural church, social and academic platforms compromises multicultural transformation in the black and white society (Andrews 2002:77). We are challenged to reconstruct national, communal and individual identities in South Africa (Van der Merwe 2000:68). 'Racism was the most potent force in creating social division in South Africa, especially with the white monopoly on political power' - racial diversity was absolutised to the extent of racial separation (Cloete 2000:1; Van Vugt 2000:32).

Another socio-cultural challenge in South Africa is the response of some of the white minorities (the DRC and socalled English-speaking churches) to a multicultural society (Cilliers \& Nell 2011; Dames 2012b; De Gruchy 2000). Further, according to Pui-lan (2005):

Because of the history of immigration, the natives are no longer outside but are already inside the metropolitan centres, and the dominant white culture does not know how to deal with the challenges of diversity and multiculturalism. (pp. 173-174)

Cilliers and Nell's (2011:3-6) application of the DRC as a case study to explore the interaction between religious and social transformation in South Africa, is illuminating in this instance. The DRC is seeking new theological frameworks to redefine its identity in a new safe haven (Cilliers \& Nell 2011:4; Dames 2012a; cf. Douglas 2007:7-9). A resistant mono-cultural 'laager' mentality amongst some white people and, ironically, also some middle-class black people, relate to a new monoclass and cultural 'enclave' tendency. The notion of a 'laager' in some white (DRC) circles in South Africa engenders a theology of living and worshipping in safe, private, cultural enclaves, whilst simultaneously discriminating against other cultures (De Beer \& Van Niekerk 2009:50-52; Kuperus 2011). Some wealthy white people (and middle-class black people) retreat into privatised gated communities, living like expats, and withdrawing from public life and engaging as little as possible in the transformed order (Cilliers \& Nell 2011; Kuperus 2011).

It is disturbing that the monocultural laager mentality is especially evident, to a large extent, in some white DR

7.The majority of South Africans desire unity, and cite class inequality as the most divisive gap in society. Most South Africans assert that race relations have improved since 1994, and do not rate race as a top source of division (race has dropped to fourth position). However, when the relationship between living standard and race category is analysed, the strong connection that continues to exist between race category is analysed, the strong connection that continues to exist between
class and race is demonstrated. Black South Africans comprise the vast majority class and race is demonstrated. Black South Africans comprise the vast majority
of the materially excluded in South Africa, a dire reality which is not experienced by most white South Africans. This is part of the legacy passed down from the apartheid system which fostered a mutually reinforcing relationship between racial discrimination and class inequality. In their 2006 book Class, Race and Inequality in South Africa, Jeremy Seekings and Nicoli Nattrass explain that although policies of economic empowerment have allowed a few black South Africans to climb the social ladder to build a more multiracial middle class, they have been less successful in uplifting the marginalised masses and undoing the apartheid legacy of disenfranchisement [Seekings \& Nattrass 2005]. As a result, intra-racial class of disenfranchisement [Seekings \& Nattrass 2005]. As a result, intra-racial class inequality has widened amongst black South Africans and, as such, did not result in the dismantling of the race and class system that underpinned apartheid. In sum, these results show that even though class is cited as the key divisive identity in South Africa, it remains intimately intertwined with race. Especially in terms of the racial make-up of material exclusion, our apartheid inheritance continues to be alive to this day. It is necessary, therefore, to think more deeply about the nature of the relationship between race and class division in South Africa' (Wale 2013:16). churches and, to a lesser extent, English-speaking churches which have remained resistant to integration and diversity, respectively (De Beer \& Van Niekerk 2009:50ff.; De Gruchy 2000:39-40). De Gruchy (2000) also observes that:

White English-speakers continued to dominate and control the English-speaking churches for many decades despite the growing number of black members within their ranks. ... even though, in contrast to the DRC, they [became] multiracial rather than segregated denominations. (p. 43)

The new middle-class black mono-class-cultural 'enclave' tendency exacerbates this resistance to breaking the historic socio-cultural and economic hegemonic conditions ('consensual social practices, social forms, and social structures produced in ... the church, the state, the school, the mass media, the political system, and the family' [McLaren 1998:182 cited in Boler \& Zembylas 2003:117]).

Esterhuyse (2009) is of the opinion that:

A serious intercultural dialogue on at least understanding the value of diversity is prevailing in South Africa. We come from a past which has had a devastating effect on the nation. The most challenging part of our journey towards the future, however, still remains the building of a workable moral consensus across cultural and other divides on what our core guiding values should be. (pp. 110-111)

The South Africa government has failed to alleviate the plight of the poor ${ }^{8}$ and there are indications that the divide between rich and poor has increased. Social transformation has lagged behind in terms of economic and political transformation (Nell 2009).

Jafta (2000) is of the opinion that:

Many people in South Africa crossed the bridge into a supposedly new society without confessing the sins of the past. Those who were previously privileged are crossing the bridge with their possessions. Those who were underprivileged are crossing with their poverty. (p. 181)

\section{Leadership and spirituality and the role of the three publics}

How are we to address socio-political challenges and social transformation of the market, from a public theology perspective in terms of the wider society, the academy and the church? Especially with regard to leadership and spirituality (Tracy 1981:5). Our discussion thus far illuminates the fact that the human issues raised in this article cannot be addressed without theological action and reflection on the transversality between the three publics. The role of spirituality in leadership has gained impetus

8. When they struggle, and economic deprivation becomes structurally entrenched over time, the most adversely affected can develop, in some instances, a sense of social marginalisation, characterised by despair and dwindling confidence in the capacity of public institutions and their leadership to address their plight. ... economic exclusion experienced by those who find themselves at the wrong end of South Africa's grossly unequal society. If these declines continue to follow their of South Africa's grossly unequal society. If these declines continue to follow their
current trajectory, the cohesive effects of public institutions will wane, and political instability will become an increasingly likely prospect. An immediate, but only partial, remedy to the current state of affairs would be to prioritise transparency, partial, remedy to the current state of affairs would be to prioritise transparency,
accountability and leadership integrity within the system to restore trust in the bona fides of key institutions' (Hofmeyr 2013:xiii). 
globally in all sectors of society (Gibbs 2005; Nell 2011; Roxburgh 2005). This new emphasis on leadership can be attributed to disillusionment with capitalist markets, hierarchy and enclave ideologies (Crossman 2010:597). Of course, the ancient church has a long history of spirituality. Consider, for instance, the contribution of the desert fathers (and mothers) and ancients scholars (Hermans \& Koerts 2013:2). However, in striving to gain scientific credibility for theology, a dichotomy of the intellect and the spiritual seems to have developed. Today, spirituality is seen as a discipline in its own right, separate from theology. Wolfteich (2009:133) points to the fact that practical theology has the critical task of supplying normative frameworks for concrete spiritualities. Spirituality on its part makes an important contribution to practical theology in that it brings life to the interaction between theory and practice.

A further commonality between spirituality and practical theology is the quest for social transformation (Bell 2008). Spirituality is important for the promotion of social change and politics. Hermans and Koerts (2013:5) define spirituality as a way of growing in discernment. They see discernment as the missing conceptual link which informs (transformational and multicultural) leadership. This 'growing in discernment' implies that spirituality is not static, but that spirituality, according to Doohan (2007:107), is a dynamic concept. It is not about prayer, but growth in prayer; not about charity, but growth in charity; not social justice, but growth in one's commitment to social justice. A key component for Dohaan is that spirituality cannot take place in isolation, but in communion with others as a process of achieving fulfilment (Hermans \& Koerts 2013:3, 9-10). Hoppe (2005:85), in her model of spirituality, incorporates similar concepts to indicate growth to wholeness, namely: meaning, connections, unity and contextual understanding, tolerance, forgiveness and acceptance.

From these definitions it is clear that spirituality cannot be marginalised to individualised, enclave and abstract expressions of faith - it manifests in public expressions of faith. This is where the link can be made between spirituality and theology (notably practical and public theology). Whereas practical theology implies the praxis of faith in concrete terms, public theology pertains to the public manifestation of the Christian faith in the church, society and the academy (Tracy 1981:5).

It is at this point that spirituality and theology, as interconnected disciplines, become relevant to social transformation in the contexts of social injustice and multiculturalism. Great public theologians such as Beyers Naudé demonstrated his spirituality in the public domain by protesting against social injustice and oppression. Naudé's spirituality and moral consciousness led him to terminate his membership in the DRC, based on the rejection of an urgent plea from the three black DR churches to unite with the DRC (Naudé 1985:5-15). Spirituality is thus very relevant to informing sacred and secular leadership on matters of social inequity, dysfunctional leadership and the challenges of multicultural societies such as in South Africa (Kovacs 2011:167).

\section{Dysfunctional leaders in liminal spaces}

Dysfunctional sacred and secular leadership praxes in the three publics exacerbate complex 21st century challenges (Tracy 1981:14-24). The challenges alluded to above are exacerbated by the dynamics of diverse cultures which are in a constant state of transition (De Gruchy 2000:39-44; Gibbs 2005:9; Nell 2011; Roxburgh 2005).

Constant demographic shifts characterise our world today (Branson \& Martínez 2011:10, 79, 490, 497; DeYoung et al. 2003:122ff.):

Stability has become instability; a defined identity has been replaced with the search for a new identity. The shattering of the [centre] has opened up a vacuum. Whilst many (mostly White) South Africans have emigrated to other countries, those remaining in South Africa seem to be 'emigrating inwardly' (cf. Durand 2002:60). They seek the safety of the enclave, rather than facing the 'other'. (Cilliers \& Nell 2011:7)

The disengagement of mostly white South Africans from concrete engagement in public life leads ultimately to spiritual fragmentation (Durand 2002:60). The tendency and patterns of 'white and black flight' from the inner cities or centres of socio-econmic power to the suburbs create demographic changes and exacerbate socio-economic, moral and spiritual leadership challenges (Durrheim et al. 2011:51-53; Venter 2008:6). 'Major socio-economic and racial fault lines persist as the IJR's ${ }^{9}$ Reconciliation Barometer and Transformation Audits continue to show each year' (Tutu 2010 in Cilliers \& Nell 2011:2). 'We cannot seek to build ... leadership for a morally transformed society through [for instance] our education system unless we transform the political, economic and social relations' (Howell 2009:148). The opportunity to create a new multicultural society is being neglected by some of the affluent and wealthy suburban charismatic and mainline churches that decentre themselves into safe 'laager' havens:

When a church simply uses the notion of cultural identity to further the interest of its own ethnic communities, particularly their privileges, and remaking the apartheid's volkskerk [people's-church] into a post-apartheid cultural church, it is not the reconciliation of justice and nonracialism. (Botman 2000:118)

It would seem that some mainline churches (Englishspeaking churches and the DRC) in South Africa continue to function with a sense of false security (Cilliers \& Nell 2011; De Beer \& Van Niekerk 2009; Gibbs 2005:13). Secular and sacred leadership in the three publics, if untransformed, are counterproductive in embracing difficult and concrete ethnic and cultural issues (Andrews 2002:107, 711; Venter 2008:542ff.). This kind of leadership is an obstacle to effective ministry in cross-cultural and multicultural contexts. Such dysfunctional leaders cause a clash of worldviews, inherent in cross-cultural and multicultural relationships (Lingenfelter g.Institute for Justice and Reconciliation. 
2008:15). The gospel is, ironically, transcultural and the life and teaching of Jesus gives Christian leaders the spiritual resources essential to meet complex and diverse challenges of interpersonal conflicts, and misunderstandings that arise when teams and followers embrace conflicting worldviews (Lingenfelter 2008:16). This calls for a new pedagogy of leadership that will have to deal with the complex challenge of building a society from culturally diverse communities (Lingenfelter 2008:20; Roxburgh 2005:20ff.). We are in need of a transformational pedagogy of leadership that can help to transcend social, cultural, racial and ethnic boundaries in order to create new habits and identities:

... not only in analysing colonial discourse or in deconstructing Western dominant regimes of knowledge, but also in examining the interdependence of the cultural terrain traversed by both the colonisers and the colonised. (Pui-lan 2005:3)

According to Roxburgh (2005:1-20), this cross-over or transversal action of leaders encompasses the ability and openness to learn from other cultures, to foster new trusting relationships, to unlearn old habits and worldviews and to relearn how to develop a new interracial, intercultural and ultimately, multicultural society characterised by reciprocal cooperation between one's own ethnic and/or cultural community and that of the other.

\section{Towards a spirituality and multicultural leadership pedagogy}

Our discussion thus far has unearthed pervasive and complex living conditions and experiences in the three publics. As stated above, our premise is that the formation of leaders and the transformation of racism and colonialised culture should not be inhibited by enclave socio-cultural and political and cultural dynamics. In as far as the latter preserve the society and culture of one group at the expense of other fellow human beings (Firet 1968:229). We concur with Freire's (1972) (Lange 1972:12) educasão problematizadora with as object conscientizacão - making aware or conscientisation - according to Pui-lan's (2005:30) theory, the decolonisation of the mind and soul. Education is about the observation of one's own living condition as problem and the solution of that problem through reflection and action (Freire 1998:107). We seek pedagogic transformational action through 'cultural revolution' as the reconstruction of the entire social order and human action to decolonise mind and soul. 'Cultural revolution' is guided and applied by conscientição which becomes impractical with technical or scientific knowledge or skills of the so-called 'linguistic or philosophical expert' (Freire 1998:115, 137). It is about critical pedagogy which seeks to analyse oppressive praxes fostering inequalities experienced especially by those who are marginalised (Zimmerman, McQueen \& Gwendolyn 2011:16). To this end, we react as holistic beings (mind, heart and will) to the complexity of our existence (Armour \& Browning 1995:19-21). Change or transformation happens when our perspectives or thinking are re-orientated - in the spiritual action of a leader in his or her active participation in a change-orientated relationship or environment.
Firet (1968) is helpful in the construction of an agogical (transformational) leadership process. It is about a reciprocal intersubjective relationship between leaders, their followers and their context in which they are called to embody and nurture humanity and responsibility. Leadership formation is a continuous agogical (transformational) process towards spiritual maturity (Firet 1968:190, 209, 216). It is at this point that we seek a pedagogical framework to form and transform the worldviews and, ultimately, the experiences and social relations of leaders. The contributions of three pedagogues who represent a significant transformational period during the 1980s and 1990s will be applied. We believe that their insights have emerged in a time of cultural shifts with considerable complex challenges. Briefly, the models which will be discussed are as follows: Firstly, Ploeger's (1995) pedagogy entails three dimensions (cognitive-cultural, social relations and subjective existential experience) and critical reflection through his human-spiritual approach. It is a reciprocal hermeneutical action process that offers us a platform for developing an integrated spirituality and multicultural leadership pedagogy. Secondly, Epperley (1989) grounds our existential experiences and understanding of complex realities in a systematic process and ethical approach within a reflective and spiritual formational approach. Thirdly, Dorr's (1990) integrated spirituality model illuminates pedagogy as dealing with the complexities of life on a personal, interpersonal and public level.

The three-dimensional model of Ploeger (1995) serves basically as the action field of hermeneutics. Hermeneutics, in this instance, deals with the question of how leaders are living and experiencing contemporary life. It reflects on their historical and existential context. The context and personal life view of leaders should be interpreted in relation to Ploeger's three-dimensional praxis, thinking, willing, living and life experience and reflection thereon within a humanspiritual or diaconal (service) approach. Hermeneutics is about critical reflection with regard to the first three dimensions and how they relate to each other (Ploeger 1995:245). The cognitive, social relations and life experience and biography are based on a leader's living context and world view (Ploeger 1995:246). Together with contemporary cultural knowledge the cognitive element forms the theoretical element. The life world, as the context for social relations and norms, is the normative and social component. The living experience of a leader and the element of value formation form the subjective component (Ploeger 1995:246). The overlapping of these matrix praxes is instrumental in intersubjective pedagogic transformational reflection and action of leaders in the three publics. It fosters a particular disposition of public wisdom (critical discernment), values and skill. Freire's (1998) pedagogy of critical reflection and action is illuminating in this regard. It can help to transform tendencies and practices which foster 'laager' mentalities or enclavement and uncritical positions on an unighteous society and hegemonic subjectivism (Ploeger 1995:246). Practical hermeneutics must have didactic application. It is only in the praxis of learning how to understand the life experience and living praxis from a leader's life and world 
view that they can develop and critically reflect on concurrent theoretical, social and subjective perspectives (Ploeger 1995:246). These elements form the basis of communicative action. Therefore, the practical application of hermeneuticalcommunicative action deals with the three dimensions, past experience, norms and values of leaders and communities, which function as frameworks for similar contemporary contexts and pedagogic praxes of freedom (Ploeger 1995:305306).

The application of the aforementioned principles is essential in the education of respectful and transparent leaders, who can create space for critical dialogue and social transformation. Ploeger's matrix praxis holds the tension and freedom to converge, overlap and diverge critical educational moments for critical dialogue (Ploeger 1995:306). This brings us to an important question: How to form spiritual leaders who will be empowered to develop spirituality and multicultural contexts in which critical dialogue and social transformation can flourish.

Epperly's (1989:324) process theology is illuminating in this instance. It provides a mystical vision of God's relationship with humankind to serve as the basis for systematic, ethically grounded spiritual formation. Ploeger (1995:113) undergirds this mystical action as an inherent dimension of his humanspirituality theory. Process theology, in line with a pedagogy of leadership, is a reflective and formational way of experiencing and understanding multicultural, neo and/or colonialised or racialised realities in terms of our deepest spiritual insights and values, such as solidarity and responsibility and accountability. An agogical leadership process may prove instrumental in this regard. Firet's (1968) agogical theory as spiritual formation focuses on three interrelated dimensions - receptivity, discretion and discernment and creativity. Leaders should base their receptivity of others on authenticity; apply trustworthy discretion or discernment in complex situations; and be creative in creating space and life praxes for others. The creativity of leaders through their spiritual action is the highest form of human-creative responsibility and freedom (Firet 1968:290). It is about becoming human or an authentic spiritual leader based on transformation as a continuous process within a broader life perspective (Firet 1968:246).

Process theology affirms human discourse enactments, experiences and responses as the concrete manifestations of the divine in everyday life (Epperly 1989:324). The pedagogic value of Epperley's mystical action can strengthen Ploeger's critical hermeneutical communicative action and Freire's $(1972,1998)$ conscientization model that seeks socio-economic, cultural and political justice and freedom. Hermeneuticalcommunicative action can help to transform moments of cognitive, cultural, social and subjective complexity or incomprehensibility through mystical enactments of God's vision as an inspirational reconfiguration of reality and human experience.
We should be mindful of the formation of multicultural leadership and the conditions for spiritual growth in terms of power issues and ethical consequences (Hall 1984:100). Multicultural leadership should be grounded in a spiritual integration model. The spiritual lives of multicultural leaders are a developmental process (Hall 1984:100-101). Spiritually matured leaders ought to support, at least some, secular leaders in society to deal with dysfunctional systems, behaviour and relationships. The educational role of leaders is to form a multicultural society, which can become a creative and transformational force in society (Hall 1984:102). Leaders are the embodiment of the contextual and historical values of individuals and the community. It is therefore crucial that leaders embody an integrated spirituality with values that inspire personal and communal growth. Dorr (1990) and Epperly (1989) are instrumental in our aim to construct an integral spirituality for the shared benefit of local communities (Johnson 2011).

Dorr's (1990:1-6) model of integral spirituality deals with anthropology, community, justice, peace and environmental issues, which correlate with Ploeger's (1995:30, 55, 117, 305) three-dimensional model (epistemology-culture, social relations and subjective existential experience), critical reflection and human-spiritual pedagogy.

Ploeger's hermeneutical question of how leaders understand or interpret their contextual and historical contexts or their contemporary lives as living experiences lies on a personal, interpersonal and public level as illuminated by Dorr (1990). This constitutes an integrative spiritual hermeneutical approach which converges and overlaps within a holistic anthropology and worldview to engender Ploeger's (1995) hermeneutical communicative action theory in terms of his theory as discussed above.

Dorr's (1990:3) model consists of three major dimensions (public, interpersonal and personal) which overlap each other. These dimensions, compared in relation with Ploeger's (1995) model, do not follow a clear logical pattern and are interrelated and dependent on each other (Dorr 1990:3). This forms a matrix praxis. The personal, interpersonal and public dimensions overlap and create new opportunities and space for spirituality where aspects such as ecology, public affairs, structural justice, interpersonal respect, personal integrity, transparency, responsibility, personal and communal prayer can be dealt with (Dorr 1990:3). Authentic multicultural relationships can be fostered through the participating community dimension, which deals with the exploration of how we relate to other cultures or diversity to build a multicultural society (Dorr 1990:4). Community prayer and public liturgical prayer are essential to develop a hermeneutical community of multiculturality to work for structural justice in society (Dorr 1990:5). In the process of developing relevant leadership spirituality for our world, the issue of structural justice is crucial. In the process of developing an effective spirituality it is essential to acknowledge that 'it is only through their culture that people can find the energy to challenge injustice effectively 
and build alternatives to the present grossly unjust structures of society' in order to embrace peace in every sphere of life, which can lead to self-transformation (Dorr 1990:5-6).

According to Epperly (1989:330), spiritual formation is not self-annihilation, but self-transformation, leading to selfexpansion to engage in multicultural experiences and praxes. Ploeger (1995) differs on this point; he does not refer to the emancipation of the self, but rather to the emancipation of others, in other words, suffering and oppressed communities. This correlates with Boler and Zembylas's (2003:111) pedagogy of discomfort that inspires leaders to move out of their comfort zones. Spiritual formation as a pedagogic imperative involves the ongoing process of creative transformation in humanity and divinity to engender healing, wholeness and justice for the common good of others.

The inclusive spirit nurtured by process spirituality embraces one's physical, social and cultural as well as spiritual life (Boler \& Zembylas 2003:330). A pedagogical human-spiritual ontology may prove valuable to create and transform contemporary 'laager' spirituality, which compartmentalises reality. The formation of leaders should not be inhibited by factual issues of socio-cultural situations - the preservation of one society and culture at the expense of other historical beings (Firet 1968:229). 'New alliances in the liberal intelligentsia with any dominant culture should be exposed without implicating moral blame' (Aronowitz 1998:17). Freire's (1998) pedagogy opposes colonial or postcolonial conditions of political, economic, technological and intellectual oppression which is always conditioned with the invalidity and negation of the collective experience of one group. The later refers to the cultural identity and language of the oppressed that lead to domestication and the indoctrination of foreign experiences, words and identity praxes. It calls for:

postcolonial imagination - a desire, a determination and a process of disengagement from the whole colonial syndrome, which takes many forms and guises. The decolonialisation process restructures the colonial process inscribed, affecting both the metropolis and the colonies. (Pui-lan 2005:2-3)

Postcolonial imagination undergirded by a mysticism of becoming, affirms the essential interrelatedness of all life, the contemplative life and the political life. Epperly's notion of interrelatedness also correlates with Dorr's integral spirituality and Ploeger's three-dimensional, reflexive human-spiritual praxis. A mysticism of becoming is inherently ecologically, anthropologically and socially responsible (Epperly 1989:331). A spirituality open to the divine dimension in the realm of politics must embrace conflict, racialisation and diversity as well as peace (Epperly 1989:332). Therefore, a pedagogy of discomfort and a critical pedagogy are instrumental for an integrative leadership spirituality to foster integrity and transparency for authentic multicultural space (Boler \& Zembylas 2003; Zimmerman et al. 2011).

\section{Where to now?}

The ultimate goal of multicultural leadership formation is the formation of creative hermeneutical-communicative action to engage in critical reflection and action to reconstruct monocultural and 'laager' realities into praxes which embrace diversity and the 'legacy of other cultures' (Hall 1984:119). However, this is where both sacred and secular leaders are defaulting. As discussed above, some mainline churches lack the diversity of ministry and freedom of authority (Hall 1984:119). Both sacred and secular leadership of the three publics have also systematically developed a theology of hierarchy in an attempt to survive historical struggles and reformations. This refers to the deeply embedded emotional dimensions that frame and shape daily habits and routines in unconscious complicity of hegemony to draw attention to the ways in which we enact and embody dominant values and assumptions, for example, about white 'Afrikaner' identity (cf. Boler \& Zembylas 2003:111):

The dark days of ethnocracy seemed to be over. However, there have been some indications that people are again retreating into ethnic categories when trying to define their identity ... The legalized borders of the enclave may have been abolished, but that does not necessarily mean that the spirit of the enclave is not still alive and well in South Africa, at least within DRC realities. (Cilliers \& Nell 2011:6)

De Gruchy's (2000:40) proposal of a chastening process for the DRC and English-speaking churches is insightful. It is about the loss of a hegemonic-political status, loss of ethnicmarket dominance and loss of moral-enclave innocence. Hegemonic and enclavement theology has systemically and pragmatically disempowered and eliminated communality or creative multicultural praxes that could develop and explore the creative power of diversity in society and the decolonisation of the mind and soul (Hall 1984:119; Pui-lan 2005:30). Communal life enactments, for instance, public prayer, dialogue and discernment, can counter rigid hierarchy and 'laager' communities (Hall 1984:119). The work of the Holy Spirit is central in the development of multicultural praxes (Hall 1984:119-120). Community hermeneutics (Venter 2008:543-544) is critical, particularly in the light of the ethnic fragmentation in Africa (Mwambazambi 2011:1, 7 of 8). Ploeger's (1995) hermeneutical communicative action approach serves as a framework for facilitating dialogue of past experiences, as a precursor to contemporary and future opportunities of freedom and justice.

The vacuum in the three publics to attend to the complexity and diversity of cultures in South Africa needs redress (Venter 2008:542). Racism and the tendency of 'white flight' and a 'laager' mentality exacerbate the engendering of a new kind of society.

\section{Nell (2009) observes that:}

In the Dutch Reformed Church ... the complex set of relationships with the other (cultural, religious, gender) is still ... the most important factor in the struggle to construct a Christian identity. (p. 240) 
Transversality between the three publics in Africa are ideal for concrete social content to a new African society in proposing horizons of new life to all humanity for a better future in our global society (Mwambazambi 2011:1, 7 of 8). To realise this ideal we will need leadership that strives for values such as authentic multicultural societies which engender social and economic justice and peace between diverse ethnic communities. The Uniting Reformed Church in Southern Africa (as an integrated multicultural church), Stellenbosch, questioned the missionary theology of its past and forged a new theological identity through the Belharpedagogy (the Confession of Belhar as witness for visible unity, reconciliation and justice and as opposed to racial segregation of church and society) (Osmer 2005:166-171). A congregational, social and ecumenical leadership initiative was established to empower sacred and secular leaders in Stellenbosch to deal with their past; their new identity; to address pervasive social challenges; and the racial divide with the dawn of the new South Africa. They established new ecumenical initiatives, a public Christian cooperation pact with Roman Catholics, charismatics, Messianic Jews and Protestants by establishing the Stellenbosch Christian Network in 2000 (Osmer 2005:172-173). Universities in South Africa have also progressed in their attempts to bridge the racial and cultural divides through teaching, research and community engagement programmes (Dames 2012a; Duncan 2010; Kritzinger \& Saayman 2011).

\section{Conclusion}

The reinvention of spiritual, multicultural and authentic leadership in the three publics is ideal to attend to the complex dynamics between church, theology and cultural issues (Branson \& Martínez 2011:367). Theology in South Africa ought to embrace racial and cultural tension with the same creativity and humility in seeking a new prophetic multicultural leadership praxis (Kritzinger \& Saayman 2011:2). Nelson Mandela and Desmond Tutu exemplify and realised spiritual multicultural leadership praxes in South Africa and across the world.

\section{Acknowledgements Competing interests}

The authors declare that they have no financial or personal relationship(s) that may have inappropriately influenced them in writing this article.

\section{Authors' contributions}

G.E.D. (University of South Africa) was the project leader, G.A.D. (University of South Africa) made conceptual contributions and both wrote the manuscript.

\section{References}

Andrews, D.P., 2002, Practical theology for black churches: Bridging black theology and African American folk religion, Kindle edn., Westminster John Knox, London, viewed 27 December 2011 from http://www.amazon.com/Practical-TheologyBlack-Churches-ebook/dp/B005LD9E2Q/ref=sr_1_6?s=digital-text\&ie=UTF8\&qid $=1330003555 \& \mathrm{sr}=1-6$

Armour, M.C. \& Browning, D., 1995, Empowering diversity without polarizing the church: Systems-sensitive leadership, College Press, Joplin, MI.
Aronowitz, S., 1998, 'Introduction', in P. Freire, Pedagogy of freedom: Ethics, democracy, and civic courage, transl. P. Clarke, pp. 1-19, Rowman \& Littlefield democracy, and civic courd
Publishers, Lanham, MD.

Batts, V., 1989, 'Extracts from Shifting the paradigms', in Social context and management workshop resources', based on the article, Modern racism: New melody for the same old tunes, pp. 18-29, paper presented at the Difficult conversations: Race, racism and transformation workshop, Embrace in association with Wits Centre for Diversity Studies and the Department of Philosophy, Practical and Systematic Theology, Unisa, February 12-13, 2013, viewed 15 January 2013, and Systematic Theology, Unisa, February 12-13, 2013, view
from http://www.embrace-org.co.za/Shifting Paradigms.pdf

Bell, E., 2008, 'Towards a critical spirituality of organization', Culture and Organization 14(3), 293-307. http://dx.doi.org/10.1080/14759550802270726

Bevans, S.B. \& Schroeder, R.P., 2004, Constants in context: A theology of mission for today, Orbis Books, New York.

Boler, M. \& Zembylas, M., 2003, 'Discomforting truths: the emotional terrain of understanding difference', in P. Trifonas (ed.), Pedagogies of difference: rethinking education for social change, pp. 110-136, Routledge Falmer, New York.

Botman, H.R., 2000, 'The church partitioned or the church reconciled? SA's theological and historical dilemma. Reconciliation as crucial quest for Africanization has to become a challenge to the academy', in W.E. Van Vugt \& G.D. Cloete (eds.), Race and reconciliation in South Africa: A multicultural dialogue in comparative Race and reconciliation in South Africa: A mult
perspective, pp. 105-119, Lexington, Oxford.

Branson, M.L. \& Martínez, J.F., 2011, Churches, cultures \& leadership: A practical theology of congregations and ethnicities, Kindle edn., IVP Academic, Downers Grove IL, viewed 18 December 2011, from http://www.amazon. com/Churches-Cultures-Leadership-Congregations-ebook/dp/B005JWJA8C/ ref=sr_1_5?s=digital-text\&ie=UTF8\&qid=1330003468\&sr=1-5

Cilliers, J. \& Nell, I.A., 2011, '"Within the enclave": Profiling South African social and religious developments since 1994', Verbum et Ecclesia 32(1), Art. \#552, 7 pages. http://dx.doi.org/10.4102.ve.v32i1.552

Clarke, P., 1998, 'Translator's notes', in P. Freire, Pedagogy of freedom: Ethics, democracy, and civic courage, pp. ix- $\mathrm{x}$, Rowman \& Littlefield Publishers, Lanham, $\mathrm{MD}$.

Cloete, D., 2000, 'South Africa and Paul's letter to the Galatians: A struggle with ethnicity and race', in W.E. Van Vugt \& G.D. Cloete (eds.), Race and reconciliation in South Africa: A multicultural dialogue in comparative perspective, $\mathrm{pp} .1-8$, Lexington, Oxford.

Cochrane, J., De Gruchy, J. \& Petersen, R., 1991, In word and deed: Towards a practical theology in social transformation, Cluster Publications, Pietermaritzburg.

Crossman, J., 2010, 'Conceptualising spiritual leadership in secular organizational contexts and its relation to transformational, servant and environmental leadership', Leadership \& Organisation Development Journal 31(7), 596-608. http://dx.doi.org/10.1108/01437731011079646

Dames, G., 2012a, 'Intercultural theological education: Towards a new future for faculties of theology at higher education institutions in South Africa', Scriptura $110,237-248$

Dames, G.E., 2012b, 'A multicultural theology of difference: A practical theological perspective', paper presented at the Black Church Activism and Contested Multiculturalism in Europe, North America, and Africa Conference, Birkbeck, University of London, 29-30th May.

De Beer, J.M. \& Van Niekerk, A.S., 2009, 'Die missionêre waarde van Belhar en die NG Kerk-familie se herenigingsgesprek (The missional value of Belhar and the DRCfamily's reunification talks)', Dutch Reformed Theological Journal 50(1/2), 50-65.

De Gruchy, J.W. 2000, 'The chastening of the English-speaking churches in South Africa', in W.E. Van Vugt \& G.D. Cloete (eds.), Race and reconciliation in South Africa: A multicultural dialogue in comparative perspective, pp. 37-51, Lexington, Africa: A
Oxford.

Degenaar, J., 2000, 'Multiculturalism: How can the human world live its difference?', in W.E. Van Vugt \& G.D. Cloete (eds.), Race and reconciliation in South Africa: A multicultural dialogue in comparative perspective, pp. 155-176, Lexington, Oxford.

DeYoung, C.P., Emerson, M.O., Yancey, G. \& Kim, K.C., 2003, United by faith: The multicultural congregation as an answer to the problem of race, Orbis, New York. http://dx.doi.org/10.1093/acprof:oso/9780195152159.001.0001

Doohan, L., 2007, Spiritual leadership: the quest for integrity, Paulist Press, New York.

Dorr, D., 1990, Integral spirituality: Resources for community, justice, peace, and the earth, Gill and MacMillan, Dublin.

Douglas, M., 2007, 'Seeing everything in black and white', in Computing in the Humanities and Social Sciences, viewed 21 October 2013, from http://projects. chass.utoronto.ca/semiotics/cyber/douglas2.pdf

Duncan, N., 2010, 'Recreating changing spaces', paper presented at the Anti-Racism Network in Higher Education (ARNHE), Back to the future: Black consciousness and those conscious of their whiteness, International Institute for the Studies in Race, Reconciliation, and Social Justice, University of the Free State, Bloemfontein, 04 August.

Durand, J., 2002, Ontluisterde wêreld: Die Afrikaner en sy kerk in 'n veranderende SuidAfrika, Lux Verbi, Wellington.

Durrheim, K., Mtose, X. \& Brown, L., 2011, Race trouble: Race, identity and inequality in post-apartheid South Africa, KZN Press, Pietermaritzburg.

Epperly, B., 1989, 'A mysticism of becoming: process theology and spiritual formation', Encounter 50(4), 323-335.

Esterhuyse, W., 2009, 'Responsible corporate citizenship and the ideas of the UN Global Compact', in G.E. Dames (ed.), Ethical leadership and the challenges of moral transformation, pp. 109-111, SUN MeDIA, Stellenbosch.

Esterline, D.V. \& Kalu, O.U. (eds.), 2006, Shaping beloved community: Multicultural theological education, Westminster John Knox, Louisville, KY. 
Firet, J., 1968, Het agogisch moment in het pastoraal optreden, Kok, Kampen.

Freire, P., 1972, Pedagogie van de onderdrukten, transl. J.E.A. Andriessen-Van der Zande \& J.P. de Vries, Antos-boeken, Baarn.

Freire, P., 1998, Pedagogy of freedom: Ethics, democracy, and civic courage, transl. P. Clarke, Rowman \& Littlefield Publishers, Lanham.

Gibbs, E., 2005, Leadership next: Changing leaders in a changing culture, InterVarsity Press, Downers Grove.

Hall, B., 1984, 'Leadership development and spiritual growth', ATR/Supplementary Series 66(9), 100-121.

Heitink, G., 1993, Praktische theologie: Geschiedenis, theorie, handelingsvelden, Kampen, Kok.

Hermans, C.A.M. \& Koerts, E., 2013, 'Towards a model of influence of spirituality on leadership: Empirical research of school leaders in Catholic schools in the Netherlands', Journal of Beliefs and Values 43(2), 1-19.

Hofmeyr, J., 2013, 'Introduction', in J. Hofmeyr \& A. Nyoka (eds.), Transformation Audit 2013: confronting exclusion, Cape Town, Institute for Justice and Reconciliation pp. ix-xiii, viewed 06 March 2013, from http://ijr.org.za/publications/pdfs/TA\%20 2013\%20text\%20and\%20cover\%20web.pdf

Hoppe, S.L., 2005, 'Spirituality and leadership: New directions for teaching and learning', New Directions for Teaching and Learning 104, 83-92. http://dx.do org $/ 10.1002 / \mathrm{tl} .217$

Howell, C., 2009, 'Building ethical leadership in and through education', in G.E. Dames (ed.), Ethical leadership and the challenges of moral transformation, pp. 147-156, SUN MeDIA, Stellenbosch.

Jafta, L.D., 2000, 'Eco-human justice and well-being', in W.E. Van Vugt \& G.D. Cloete (eds.), Race and reconciliation in South Africa: a multicultural dialogue in comparative perspective, pp. 171-185, Lexington, Oxford.

Johnson, L.F., 2011, Drinking from the same well: Cross-cultural concerns in pastoral care and counseling, Pickwick, Eugene, OR.

Kovacs, K.E., 2011, The relational theology of James E. Loder: Encounter and conviction, Peter Lang, New York, NY.

Kritzinger, J.N.J. \& Saayman, W., 2011, David J. Bosch, prophetic integrity, cruciform praxis, Cluster Publications, Dorpspruit.

Kuperus, T., 2011, 'The political role and democratic contribution of churches in post-apartheid South Africa', Journal of Church and State 53(2), 278-306, viewed 08 February 2012, from http://jcs.oxfordjournals.org/content/53/2/278.full. pdf+html

Lange, E., 1972, 'Foreword', in P. Freire, Pedagogy van de onderdrukten, transl. J.E.A. Andriessen-Van der Zande \& J.P. de Vries, pp. 5-22, Antos-boeken, Baarn.

Lingenfelter, S.G., 2008, Leading cross-culturally: covenant relationships for effective Christian leadership, Baker Academic, Grand Rapids, MI

Mwambazambi, K., 2011, 'A missiological reflection on African ecclesiology', Verbum et Ecclesia 32(1), Art. \#482, 8 pages. http://dx.doi.org/10.4102/ve.v32i1.482
Naudé, C.F., 1985, "'My seven lean years": Forum on Christianity in the Southern African context', Journal of Theology for Southern Africa 51, 5-15.

Nell, I.A., 2009, 'The tears of xenophobia: Preaching and violence from a South African perspective', Practical Theology in South Africa 24(2), 229-247.

Nell, I.A., 2011, 'Embodied leadership: Paradigm shifts in the leadership of a local URCSA congregation', Dutch Reformed Theological Journal 52(1/2), 148-160.

Osmer, R.R., 2005, The teaching ministry of congregations, John Knox, Louisville, KY.

Osmer, R. R., 2008, Practical theology: An introduction, Eerdmans, Grand Rapids, MI.

Pui-lan, K., 2005, Postcolonial imagination and feminist theology, Westminster John Knox, Louisville, KY.

Ploeger, A.K., 1995, Inleiding in de Godsdienstpedagogiek, Kok, Kampen.

Roxburgh, A.J., 2005, The sky is falling!?!, ACI Publishing, Eagle, ID.

Schoeman, K., Laubscher, M., Pali, P. \& Van den Berg, J-A., 2012, 'Practical theology at a public university: the road travelled and the road ahead at the University of the Free State', in R. Venter \& F. Tolmie (eds.), Transforming theological knowledge: Essays on theology and the university after apartheid, pp. 127-146, SUN MeDIA, Bloemfontein.

Taylor, S., 2005, The out of bounds church? Learning to create a community of faith in a culture of change, Zondervan, Grand Rapids MI.

Tracy, D., 1981, 'Defending the public character of theology', Christian Century 1, 350-356.

Van der Merwe, W.L., 2000, 'African philosophy in a multicultural society', in W.E. Van Vugt \& G.D. Cloete (eds.), Race and reconciliation in South Africa: A multicultura dialogue in comparative perspective, pp. 167-170, Lexington, Oxford.

Van Rooi, L., 2010, 'Identity boundaries and the Eucharist: In search of the unity, catholicity and apostolicity of the church from the fringes of the Kalahari Desert', Dutch Reformed Theological Journal 51(1/2), 176-185.

Van Vugt, W.E., 2000, 'British immigration during the nineteenth century: The American and South African experience', in W.E. Van Vugt \& G.D. Cloete (eds.), Race and reconciliation in South Africa: A multicultural dialogue in comparative perspective, pp. 19-36, Lexington, Oxford.

Venter, R., 2008, 'Onderweg na 'n teologie van interkulturaliteit: 'n Trinitariese perspektief', Verbum et Ecclesia, 29(2), 542-561. http://dx.doi.org/10.4102/ ve.v29i2.48

Wale, K., 2013, 'Confronting exclusion: Time for radical reconciliation, SA Reconciliation Barometer Survey: 2013 report', in SA Reconciliation Barometer Blog, viewed on 06 March 2014, from http://reconciliationbarometer.org/wpcontent/uploads/2013/12/IJR-Barometer-Report-2013-22Nov1635.pdf

Wolfteich, C., 2009, 'Animating questions: Spirituality and practical theology', International Journal of Practical Theology 13, 121-143. http://dx.dol. org/10.1515/IJPT.2009.7

Zimmerman, L.W., McQueen, T. \& Gwendolyn, G., 2011, 'Connections, interconnections, and disconnections: The impact of race, class and gender in the university classroom', Journal of Theory Construction and Testing, 11(1), 16-21, viewed 24 November 2011, from http://rpgaeun.unisa.ac.za.ebsc/web/ehost pdf/viewer.pdf/ 